\title{
POTRET EVALUASI PEMBELAJARAN DARING (E-LEARNING) MAHASISWA KESEHATAN DIMASA PANDEMI COVID-19
}

\author{
Lisa Dwi Astuti*, Sintikhewati Yenly Sucipto** \\ STIKes Panti Wilasa Semarang, Jl Ciliwung IX No 1 Semarang 50121. \\ stikespantiwilasa@gmail.com
}

\begin{abstract}
ABSTRAK
Pembelajaran dengan metode konvesional (tatap muka) saat ini tidak memungkinkan untuk dilaksanakan di masa pandemic COVID-19, namun kompetensi dan ketercapaian tujuan pembelajaran merupakan hal yang mutlak untuk dikuasai mahasiswa. Salah satu alternatif yang dapat digunakan untuk mengatasi kendala tersebut adalah dengan pembelajaran daring. Penelitian ini bertujuan untuk memberikan gambaran evaluasi pelaksanaan pembelajaran daring bagi mahasiswa kesehatan di Stikes Panti Wilasa Semarang. Jenis penelitian evaluasi program, metode kuantitatif dengan pendekatan deskriptif, menggunakan metode evaluasi program CIPP. Jumlah sampel 68 responden yang dipilih secara simple random sampling. Pengumpulan data dengan kuesioner yang dibagikan dalam whatsapp group. Hasil penelitian ini menunjukkan selama pembelajaran daring 42,65\% responden berada di kost/rumah di pulau Jawa, 95,59\% responden mampu mengoperasikan sarana belajar secara mandiri, 47,05\% responden menggunakan sarana handphone dan laptop pribadi, 80,88\% responden menggunakan kuota internet, 94,12\% belum pernah mendapatkan bantuan kuota internet, $76,47 \%$ responden mengalami kendala saat pembelajaran daring, 47,05\% menggunakan aplikasi google classroom, 69,12\% responden menilai pembelajaran daring sesuai RPS, $39,71 \%$ responden menilai jadwal perkuliahan kurang sesuai dengan jadwal kuliah, 58,82\% responden cukup paham dengan materi yang disampaikan.
\end{abstract}

Kata kunci : evaluasi, pembelajaran daring, mahasiswa

\section{ABSTRACT}

Learning using the conventional method (face-to-face) is currently not possible to be carried out during the COVID-19 pandemic, however competence and achievement of learning objectives are essential for students. One alternative that can be used to overcome these obstacles is online learning (e-learning). This study aims to provide an overview of the evaluation of the implementation of e-learning for health students at Stikes Panti Wilasa Semarang. This type of program evaluation research, quantitative method with a descriptive approach, using the CIPP program evaluation method. The number of samples was 68 respondents who were selected by simple random sampling. Collecting data by means of a questionnaire distributed in the WhatsApp group. The results of this study indicate that during online learning $42.65 \%$ of respondents are in a boarding house / house on the island of Java, 95.59\% of respondents are able to operate learning facilities independently, $47.05 \%$ of respondents use personal cellphones and laptops, $80.88 \%$ of respondents using internet quota, $94.12 \%$ have never received internet quota assistance, $76.47 \%$ of respondents experienced problems when learning online, $47.05 \%$ used the google classroom application, $69.12 \%$ of respondents rated online learning according to RPS, $39.71 \%$ Respondents considered the lecture schedule was not in accordance with the class schedule, $58.82 \%$ of respondents quite understood the material presented.

Keywords: evaluation, online learning, student 


\section{PENDAHULUAN}

Virus SARS-Cov2 (COVID-19) secara resmi dideklarasikan oleh World Health Organization (WHO) sebagai pandemi pada tanggal 9 Maret 2020. Hal tersebut didasarkan pada fakta bahwa virus tersebut telah menyebar secara luas di seluruh dunia. Hingga tanggal 12 Oktober 2020, lebih dari 37.745.942 kasus telah dilaporkan lebih dari 189 negara dan wilayah seluruh dunia dan mengakibatkan lebih dari 1.079.963 orang meninggal dunia. Angka kejadian COVID-19 di Indonesia per tanggal 12 Oktober 2020 yaitu sebesar 336.716 kasus dan 11.935 orang meninggal dunia, dengan sebaran kejadian di 34 propinsi di seluruh Indonesia.

COVID-19 dapat menular melalui percikan-percikan dari mulut atau hidung saat orang yang terkena COVID-19 batuk, bersin, atau berbicara. Pada umumnya virus corona dapat mengakibatkan gejala yang ringan hingga sedang seperti demam, batuk, kehilangan kemampuan membau, dan rasa lelah, serta secara normal dapat sembuh dalam waktu beberapa minggu. Protokol kesehatan yang ditetapkan pemerintah yaitu penggunaan masker saat beraktivitas keluar rumah, menjaga jarak 1-1,5 meter saat beraktivitas, dan mencuci tangan dengan sabun dan air mengalir.

Pandemi COVID-19 yang

berlangsung saat ini membawa angin perubahan di hampir semua tatanan yang ada baik dari segi aspek ekonomi, sosial budaya, politik, kesehatan, dan juga pendidikan. Saat ini di Indonesia, terdapat 45 juta anak usia sekolah dasar dan menengah serta 7,5 juta mahasiswa harus melaksanakan pembelajaran dari rumah. Hal tersebut memaksa siswa, mahasiswa, orang tua, guru/dosen untuk beradaptasi dengan cepat sehingga dapat meminimalkan ketertinggalan materi pengajaran dan kompetensi yang seharusnya didapatkan oleh siswa/mahasiswa di sekolah/perguruan tinggi.

Surat edaran Kementerian pendidikan dan kebudayaan No.15 tahun 2020 tentang pedoman penyelenggaraan belajar dari rumah dalam masa darurat penyebaran COVID-19 menyebutkan bahwa penyelenggaraan belajar dari rumah harus senantiasa memperhatikan pelaksanaan protokol kesehatan. Surat edaran tersebut juga menjelaskan metode pelaksanaan pembelajaran dapat menggunakan metode dalam jaringan/daring dan pembelajaran diluar jaringan/luring (jika kondisi memungkinkan/untuk pembelajaran yang terkait dengan aspek keterampilan penting).

Perubahan metode belajar yang semula konservatif menjadi pembelajaran daring, akan membawa perubahan yang signifikan dalam proses pembelajaran. Dosen sebagai pengajar dan mahasiswa harus beradaptasi dengan kendala yang mungkin muncul selama proses pembelajaran daring baik karena faktor internal maupun faktor eksternal.

Berdasarkan hal tersebut diatas, rumusan masalah yang peneliti tetapkan adalah : Bagaimanakah potret evaluasi pelaksanaan pembelajaran daring selama masa pandemi COVID-19 pada mahasiswa STIKes Panti Wilasa Semarang?

\section{METODE}

Jenis penelitian yang dilaksanakan adalah evaluasi program. Model evaluasi yang digunakan dalam penelitian ini adalah CIPP (Context, Input, Process, Product). Model evaluasi CIPP bertujuan membandingkan kinerja dari berbagai dimensi program dengan kriteria tertentu sehingga akan dihasilkan deskripsi dan jugdgement tentang kekuatan dan kelemahan program yang 
dievaluasi (Stufflebeum, Ohio State University;1971).

Metode yang digunakan dalam penelitian ini adalah kuantitatif dengan pendekatan deskriptif. Penelitian ini diharapkan dapat memberikan gambaran mengenai pelaksanaan pembelajaran daring di masa pandemi Covid-19 di lingkungan STIKes Panti Wilasa Semarang selama periode awal pandemi bulan Maret sampai dengan bulan September 2020.

Sampel penelitian yang digunakan dalam penelitian ini sejumlah 68 mahasiswa dari 90 mahasiswa yang memenuhi kriteria secara simple random sampling. Jenis data yang digunakan dalam evaluasi pembelajaran daring (e-learning) ini adalah data primer yang berasal dari responden yaitu mahasiswa dan data sekunder yang berasal dari rekap kehadiran. Instrumen penelitian yang digunakan dalam penelitian ini adalah kuesioner tertutup. Kuesioner disusun dalam format Google form dan dikirimkan dalam Whatsapp Group. Responden diminta untuk mengisi angket dengan memberi tanda pada pada jawaban yang paling sesuai dalam kondisinya.

\section{HASIL PENELITIAN}

Hasil penelitian menggambarkan dimensi evaluasi sebaai berikut :

\section{a. Dimensi Context}

Tabel 1. Distribusi responden berdasarkan lokasi pembelajaran daring

\begin{tabular}{|l|c|c|}
\hline $\begin{array}{c}\text { Lokasi } \\
\text { mahasiswa }\end{array}$ & Frekuensi & $\begin{array}{c}\text { Prosentase } \\
(\%)\end{array}$ \\
\hline Asrama & 19 & 27,94 \\
\hline $\begin{array}{l}\text { Kost/rumah } \\
\text { Pulau Jawa }\end{array}$ & 29 & 42,65 \\
\hline $\begin{array}{l}\text { Rumah Luar } \\
\text { Jawa }\end{array}$ & 20 & 29,41 \\
\hline Total & 68 & 100 \\
\hline
\end{tabular}

\section{b. Dimensi Input}

Tabel 2. Kemampuan pengoperasian media pembelajaran daring diawal program belajar dari rumah.

\begin{tabular}{|l|c|c|}
\hline $\begin{array}{l}\text { Kemampuan } \\
\text { pengoperasian media } \\
\text { pembelajaran daring } \\
\text { diawal program belajar } \\
\text { dari rumah }\end{array}$ & Frekuensi & $\begin{array}{c}\text { Prosentase } \\
(\%)\end{array}$ \\
\hline Bisa mandiri & 53 & 77,94 \\
\hline Bisa dengan bantuan & 12 & 17,65 \\
\hline Tidak bisa & 3 & 4,41 \\
\hline Total & 68 & 100 \\
\hline
\end{tabular}

Tabel 3. Kemampuan pengoperasian media pembelajaran daring saat ini.

\begin{tabular}{|l|c|c|}
\hline $\begin{array}{l}\text { Kemampuan } \\
\text { pengoperasian media } \\
\text { pembelajaran daring } \\
\text { saat ini }\end{array}$ & Frekuensi & $\begin{array}{c}\text { Prosentase } \\
(\%)\end{array}$ \\
\hline Bisa mandiri & 65 & 95,59 \\
\hline Bisa dengan bantuan & 3 & 4,41 \\
\hline Tidak bisa & 0 & 0 \\
\hline Total & 68 & 100 \\
\hline
\end{tabular}

Tabel 4. Media yang digunakan saat pembelajaran daring

\begin{tabular}{|l|c|c|}
\hline $\begin{array}{l}\text { Media yang } \\
\text { digunakan saat } \\
\text { pembelajaran daring }\end{array}$ & Frekuensi & $\begin{array}{c}\text { Prosentase } \\
(\%)\end{array}$ \\
\hline Hp pribadi & 24 & 35,29 \\
\hline Laptop pribadi & 5 & 7,35 \\
\hline Laptop pinjaman & 3 & 4,41 \\
\hline $\begin{array}{l}\text { Hp Pribadi \& laptop } \\
\text { pribadi }\end{array}$ & 32 & 47,06 \\
\hline $\begin{array}{l}\text { Hp Pribadi \& laptop } \\
\text { pinjaman }\end{array}$ & 4 & 5,88 \\
\hline Total & 68 & 100 \\
\hline
\end{tabular}

Tabel 5. Sumber jaringan internet

\begin{tabular}{|l|c|c|}
\hline $\begin{array}{c}\text { Sumber jaringan } \\
\text { internet }\end{array}$ & Frekuensi & $\begin{array}{c}\text { Prosentase } \\
(\%)\end{array}$ \\
\hline WIFI/hot spot & 13 & 19,12 \\
\hline Kuota pribadi & 55 & 80,88 \\
\hline Total & 68 & 100 \\
\hline
\end{tabular}


Tabel 6. Kendala signal internet saat pembelajaan

\begin{tabular}{|l|c|c|}
\hline $\begin{array}{l}\text { Kendala signal } \\
\text { internet } \\
\text { pembelajaran }\end{array}$ & Frekuensi & $\begin{array}{c}\text { Prosentase } \\
(\%)\end{array}$ \\
\hline Ada kendala & 52 & 76,47 \\
\hline Tidak Ada kendala & 16 & 23,53 \\
\hline Total & 68 & 100 \\
\hline
\end{tabular}

Tabel 7. Alokasi dana yang digunakan untuk kuota internet dalam 1 bulan

\begin{tabular}{|l|c|c|}
\hline $\begin{array}{l}\text { Alokasi dana yang } \\
\text { digunakan untuk } \\
\text { kuota internet dalam } \\
1 \text { bulan }\end{array}$ & Frekuensi & $\begin{array}{c}\text { Prosentase } \\
(\%)\end{array}$ \\
\hline$<$ Rp 50.000 & 2 & 2,29 \\
\hline Rp. 50.000-100.000 & 27 & 39,71 \\
\hline Rp 100.000-200.000 & 28 & 41,18 \\
\hline >Rp. 200.000 & 11 & 16,18 \\
\hline Total & 68 & 100 \\
\hline
\end{tabular}

Tabel 8. Bantuan kuota untuk pembelajaran daring

\begin{tabular}{|l|c|c|}
\hline $\begin{array}{l}\text { Bantuan kuota untuk } \\
\text { pembelajaran daring }\end{array}$ & Frekuensi & $\begin{array}{c}\text { Prosentase } \\
(\%)\end{array}$ \\
\hline Belum pernah & 64 & 94,12 \\
\hline Pernah 1x & 4 & 5,88 \\
\hline Total & 68 & 100 \\
\hline
\end{tabular}

\section{c. Dimensi Process}

Tabel 9. Media yang digunakan selama pembelajaran daring

\begin{tabular}{|c|c|c|}
\hline $\begin{array}{l}\text { Media yang digunakan } \\
\text { selama pembelajaran } \\
\text { daring }\end{array}$ & Frekuensi & $\begin{array}{c}\text { Prosentase } \\
(\%)\end{array}$ \\
\hline 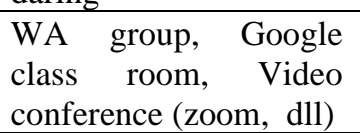 & 45 & 66,18 \\
\hline 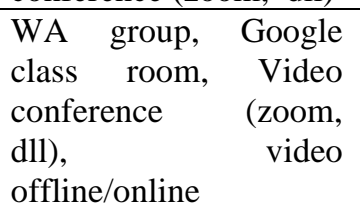 & 19 & 27,94 \\
\hline 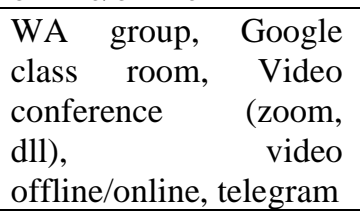 & 4 & 5,88 \\
\hline Total & 68 & 100 \\
\hline
\end{tabular}

Tabel 10. Media yang paling sering digunakan untuk pembelajaran daring

\begin{tabular}{|l|c|c|}
\hline $\begin{array}{l}\text { Media yang paling } \\
\text { sering digunakan untuk } \\
\text { pembelajaran daring }\end{array}$ & Frekuensi & $\begin{array}{c}\text { Prosentase } \\
(\%)\end{array}$ \\
\hline WA Group & 20 & 29,41 \\
\hline Google classroom & 32 & 47,05 \\
\hline Video conference & 12 & 17,64 \\
\hline Video online/offline & 4 & 5,88 \\
\hline Total & 68 & 100 \\
\hline
\end{tabular}

Tabel 11. Kesesuaian pembelajaran daring dengan RPS

\begin{tabular}{|l|c|c|}
\hline $\begin{array}{l}\text { Kesesuaian pembelajaran } \\
\text { daring dengan RPS }\end{array}$ & Frekuensi & $\begin{array}{c}\text { Prosentase } \\
(\%)\end{array}$ \\
\hline Sangat baik & 2 & 2,94 \\
\hline Baik & 47 & 69,12 \\
\hline Kurang baik & 19 & 27,94 \\
\hline Total & 68 & 100 \\
\hline
\end{tabular}

Tabel 12. Kesesuaian pelaksanaan jadwal kuliah selama pembelajaran daring

\begin{tabular}{|l|c|c|}
\hline $\begin{array}{l}\text { Kesesuaian pelaksanaan } \\
\text { jadwal kuliah selama } \\
\text { pembelajaran daring }\end{array}$ & Frekuensi & $\begin{array}{c}\text { Prosentase } \\
(\%)\end{array}$ \\
\hline Sangat baik & 3 & 4,41 \\
\hline Baik & 38 & 55,88 \\
\hline Kurang baik & 27 & 39,71 \\
\hline Total & 68 & 100 \\
\hline
\end{tabular}

Tabel 13. Koordinasi dosen, mahasiswa, dan administrasi akademik selama pembelajaran daring

\begin{tabular}{|l|c|c|}
\hline $\begin{array}{l}\text { Koordinasi dosen, } \\
\text { mahasiswa, Frekuensi } \\
\text { administrasi akademik } \\
\text { selama pembelajaran } \\
\text { daring }\end{array}$ & $\begin{array}{r}\text { Prosentase } \\
(\%)\end{array}$ \\
\hline Sangat baik & 4 & 5,88 \\
\hline Baik & 52 & 76,47 \\
\hline Kurangbaik & 12 & 17,65 \\
\hline Total & 68 & 100 \\
\hline
\end{tabular}

Tabel 14. Interaksi dosen dan mahasiswa saat pembelajaran daring

\begin{tabular}{|l|c|c|}
\hline $\begin{array}{l}\text { Interaksi dosen dan } \\
\text { mahasiswa } \\
\text { pembelajaran daring }\end{array}$ & Frekuensi & $\begin{array}{c}\text { Prosentase } \\
(\%)\end{array}$ \\
\hline Sangat baik & 4 & 5,88 \\
\hline Baik & 55 & 80,88 \\
\hline Kurang baik & 9 & 13,24 \\
\hline Total & 68 & 100 \\
\hline
\end{tabular}


Tabel 15. Tingkat ketertarikan mahasiswa terhadap pembelajaran daring

\begin{tabular}{|l|c|c|}
\hline $\begin{array}{l}\text { Tingkat ketertarikan } \\
\text { mahasiswa terhadap } \\
\text { pembelajaran daring }\end{array}$ & Frekuensi & $\begin{array}{c}\text { Prosentase } \\
(\%)\end{array}$ \\
\hline Sangat tertarik & 2 & 2,94 \\
\hline Biasa saja & 48 & 70,59 \\
\hline Kurang tertarik & 18 & 26,47 \\
\hline Total & 68 & 100 \\
\hline
\end{tabular}

Tabel 16. Kualitas bahan ajar dosen selama pembelajaran daring

\begin{tabular}{|l|c|c|}
\hline $\begin{array}{l}\text { Kualitas bahan ajar } \\
\text { dosen selama } \\
\text { pembelajaran daring }\end{array}$ & Frekuensi & $\begin{array}{c}\text { Prosentase } \\
(\%)\end{array}$ \\
\hline Sanngat berkualitas & 12 & 17,65 \\
\hline Cukup berkualitas & 52 & 76,47 \\
\hline Kurang berkualitas & 4 & 5,88 \\
\hline Total & 68 & 100 \\
\hline
\end{tabular}

Tabel 17. Data responden yang melewatkan jadwal perkuliahan daring

\begin{tabular}{|l|c|c|}
\hline $\begin{array}{l}\text { Responden yang } \\
\text { melewatkan jadwal } \\
\text { perkuliahan daring }\end{array}$ & Frekuensi & $\begin{array}{c}\text { Prosentase } \\
(\%)\end{array}$ \\
\hline Tidak pernah & 51 & 75 \\
\hline Kadang-kadang & 17 & 25 \\
\hline Selalu & 0 & 0 \\
\hline Total & 68 & 100 \\
\hline
\end{tabular}

Tabel 18. Data responden yang melewatkan jadwal pengumpulan tugas daring

\begin{tabular}{|l|c|c|}
\hline $\begin{array}{l}\text { Responden yang } \\
\text { melewatkan } \\
\text { pengumpulan } \\
\text { daring }\end{array}$ & Frekuensi & $\begin{array}{c}\text { Prosentase } \\
(\%)\end{array}$ \\
\hline Tidak pernah & 47 & 69,11 \\
\hline Kadang-kadang & 21 & 30,88 \\
\hline Selalu & 0 & 0 \\
\hline Total & 68 & 100 \\
\hline
\end{tabular}

Tabel 19. Tingkat kesulitan mahasiswa dalam membagi waktu antara perkuliahan, tugas, dan pekerjaan rumah

\begin{tabular}{|l|c|c|}
\hline $\begin{array}{l}\text { Tingkat kesulitan } \\
\text { mahasiswa dalam } \\
\text { membagi waktu antara } \\
\begin{array}{l}\text { perkuliahan, tugas, dan } \\
\text { pekerjaan rumah }\end{array}\end{array}$ & $\begin{array}{c}\text { Frekuens } \\
\mathrm{i}\end{array}$ & $\begin{array}{c}\text { Prosentase } \\
(\%)\end{array}$ \\
\hline Tidak sulit & 31 & 45,59 \\
\hline Sulit & 29 & 42,65 \\
\hline Sulit sekali & 8 & 11,76 \\
\hline Total & 68 & 100 \\
\hline
\end{tabular}

\section{d. Dimensi Product}

Tabel 20. Tingkat pemahaman mahasiswa terhadap materi perkuliahan dengan pembelajaran daring

\begin{tabular}{|l|c|c|}
\hline $\begin{array}{l}\text { Tingkat pemahaman } \\
\text { mahasiswa terhadap materi } \\
\text { perkuliahan dengan } \\
\text { pembelajaran daring }\end{array}$ & Frekuensi & $\begin{array}{c}\text { Prosentase } \\
(\%)\end{array}$ \\
\hline Sangat paham & 0 & 0 \\
\hline Cukup paham & 40 & 58,82 \\
\hline Kurang paham & 28 & 41,18 \\
\hline Total & 68 & 100 \\
\hline
\end{tabular}

\section{PEMBAHASAN}

Pembelajaran daring (e- learning) dalam dunia pendidikan merupakan sebuah inovasi yang bertujuan untuk menyampaikan informasi kepada peserta didik melalui media elektronik dengan tujuan meningkatkan pengetahuan, keterampilan serta kinerja siswa. Transformasi pendidikan dengan pembelajaran daring membawa perubahan baik dari segi content (isi) dan system yang berubah menjadi serba digital. Pembelajaran daring didefinisikan sebagai media pembelajaran jarak jauh yang digunakan untuk menunjang proses belajar baik formal atau informal, bertujuan menghilangkan batasan jarak dengan menggunakan eksternet video tape, DVD, TV, handphone, dll atau internet (Kurniawan \& Nasir, 2014). Trend pembelajaran digital semakin marak dimasa pandemi COVID-19.

Dimensi context dalam penelitian ini memberikan gambaran bahwa sebagian besar responden $(42,65 \%)$ pada bulan Maret-September 2020 mengikuti pembelajaran daring di kost/rumah yang berlokasi di pulau Jawa. Hal ini memberikan harapan bahwa tidak ada kendala bagi mahasiswa dalam mengikuti pembelajaran daring mengingat pulau jawa sudah memiliki jaringan internet yang terkoneksi dengan baik dan stabil (Menkominfo, 2020). 
Terdapat $29,41 \%$ responden yang berada di tempat tinggal luar pulau Jawa, menurut data kemahasiswaan, responden yang ada di luar pulau Jawa sebagian besar berada di Nusa Tenggara Timur. Hal tersebut membawa sedikit kekhawatiran mengingat pentingnya fasilitas jaringan internet yang baik dalam pelaksanaan pembelajaran daring. Jaringan internet yang di Indonesia saat ini masih memiliki berbagai sisi kekurangan dalam mengingat letak geografis laut dan kepulauan (Menkominfo, 2020). Cakupan internet dan penyediaan bandwidth internet yang kurang memadai merupakan masalah infrastruktur yang membawa permasalahan pada proses pembelajaran daring.

Faktor kesiapan siswa baik sumber daya manusia dan sarana prasarana dalam melaksanakan pembelajaran daring sangat penting. Kemampuan mengoperasionalkan media pembelajaran yang dimiliki juga sangat mempengaruhi keberhasilan pelaksanaan pembelajaran daring. Dimensi input dalam penelitian ini menggambarkan dua proses input yaitu input sumber daya manusia (SDM) dan input sarana prasarana. Pada awal pandemi COVID-19, masih terdapat $17,65 \%$ responden yang memerlukan bantuan dalam menggunakan media pembelajaran dan $4,41 \%$ responden tidak bisa dalam mengoperasikan media pembelajaran daring secara mandiri. Hal ini jika dibiarkan akan menjadi kendala yang sangat besar dalam pelaksanaan pembelajaran daring. Namun hal tersebut sudah dapat teratasi dengan baik, pada bulan September 2020 sebagian besar responden $(95,59 \%) \quad$ mampu mengoperasikan media pembelajaran daring secara mandiri dan $4,41 \%$ responden masih memerlukan bantuan.

Sebagian besar responden $(47,06 \%)$ menggunakan handphone dan laptop milik pribadi, sehingga tidak ada kendala dalam penyediaan sarana media belajar. Terdapat $88 \%$ responden menggunakan jaringan internet kuota pribadi. Jika dikaitkan dengan kemampuan akses internet, terdapat $76,47 \%$ responden yang mengalami kendala dalam mengakses pembelajaran daring yaitu koneksi jaringan internet yang tidak stabil selama pelaksanaan pembelajaran daring.

Kemampuan finansial ekonomi dan dukungan keluarga sangat diperlukan selama pelaksanaan pembelajaran daring. Terlebih untuk pengadaan fasilitas kuota belajar siswa. Terdapat $41,18 \%$ responden mengeluarkan biaya $\mathrm{Rp}$ 100.000,00-Rp 200.000,00 untuk pembelian kuota internet dalam 1 bulan, dan 94,12\% responden belum pernah mendapatkan bantuan kuota. Perlu perhatian pemerintah dan pihak perguruan tinggi dalam penyediaan bantuan kuota intermet, sehingga dapat meringankan beban mahasiswa dan keluarga dalam penyediaan kuota belajar.

Selain faktor mahasiswa, dosen dan tenaga kependidikan memiliki peran penting dalam menjadikan proses pembelajaran daring berhasil. Ketepatan dala pemilihan media, metode pembelajaran, dan pelaksanaan administrasi akademik harus berjalan baik. Dimensi process pada penelitian ini menggambarkan pelaksanaan proses pembelajaran daring. Terdapat $66,18 \%$ responden menyatakan bahwa aplikasi yang digunakan dalam pembelajaran yaitu Whatsapp group, google classroom, video conference (zoom, teamlink, dll), dan aplikasi yang paling sering digunakan $47,05 \%$ adalah google classroom. Penggunaan aplikasi dalam pembelajaran daring harus melalui pertimbangan yang matang, harus ditentukan apakah aplikasi tersebut sesuai dengan tujuan mata kuliah yang ingin dicapai. Mahasiswa kesehatan memiliki target kompetensi dalam pembelajaran praktik, aplikasi pembelajaran seperti video conference dapat membantu meminimalkan gap 
yang terjadi selama proses pembelajaran praktik secara daring.

Pelaksanaan pembelajaran daring $69,12 \%$ telah sesuai dengan rencana pembelajaran semester, dan $76,47 \%$ responden menyatakan koordinasi antara dosen, mahasiswa, dan administrasi akademik dalam pembelajaran daring baik. $80,88 \%$ responden menilai bahwa interaksi antara dosen dan mahasiswa selama proses pembelajaran berlangsung baik.

Sebanyak $55,88 \%$ responden menyatakan bahwa perkuliahan daring telah sesuai dengan jadwal perkuliahan, namun masih terdapat $39,71 \%$ responden yang menyatakan jadwal perkuliahan daring tidak sesuai dengan jadwal perkuliahan seharusnya. Hal ini perlu mendapatkan perhatian khusus, karena ketepatan jadwal perkuliahan memiliki pengaruh yang penting terhadap proses pencapaian tahapan kompetensi mahasiswa.

Media pembelajaran memegang peran penting dalam pembelajaran terutama dalam pembelajaran daring. Media pembelajaran harus jelas, mudah diterima mahasiswa dan mampu menjembatani gap yang terjadi dan hilangnya nuansa pembelajaran yang biasa dilaksanakan didalam kelas. Tingkat ketertarikan responden terhadap pelaksanaan pembelajaran daring sebesar $70,59 \%$. Terdapat $76,47 \%$ responden menilai bahan ajar yang diberikan dalam pembelajaran daring baik. Terdapat $77 \%$ resonden yang menyatakan tidak pernah melewatkan jadwal kuliah, dan $69,11 \%$ tidak pernah melewatkan jadwal pengumpulan tugas yang diberikan dosen. Namun hal ini tidak sejalan dengan pernyataan responden yang merasa kesulitan dengan pembagian waktu antara perkuliahan, pengerjaan tugas dan pekerjaan dirumah yaitu sebesar $42,65 \%$.

Dimensi product dalam penelitian ini menggambarkan hasil yang tergambar dari pelaksanaan pembelajaran daring. Bedasarkan data primer kehadiran mahasiswa, tercatat $85 \%$ mahasiswa mengikuti perkuliahan daring sesuai jadwal. Terdapat selisih yang tipis antara responden yang menyatakan tingkat pemahamannya baik terhadap materi yang disampaikan yaitu sejumlah 58,82\% dibandingkan dengan $41,18 \%$ responden yang menyatakan kurang paham dengan materi yang disampaikan secara daring. Hal tersebut memerlukan tidak lanjut agar hasil luaran berupa nilai ujian serta pencapaian kompetensi mahasiswa tidak terganggu.

\section{SIMPULAN \& SARAN Simpulan}

Lokasi keberadaan mahasiswa dalam pembelajaran daring menentukan tingkat keberhasilan akses terhadap jaringan internet, sebagian besar responden bergantung pada kuota internet pribadi. Sarana prasarana yang dimiliki responden dan kemampuan mengoperasikan sudah cukup baik untuk mendukung berlangsungnya pembelajaran daring. Aplikasi pembelajaran daring yang sering digunakan adalah google classroom. Jadwal pelaksanaan kuliah daring masih kurang sesuai dengan jadwal yang ditetapkan. Responden masih ada yang mengalami kesulitan dalam membagi waktu antara perkuliahan, mengerjakan tugas, dan pekerjaan rumah.

\section{Saran}

Pihak kampus perlu memfasilitasi mahasiswa dengan pemberian bantuan kuota. Dosen perlu memilih penggunaan aplikasi dan metode pembelajaran dengan bijak dan menyesuaian capaian level kometensi yang harus dicapai mahasiswa. Dosen dan mahasiswa perlu meningkatkan minat dan komitmen dalam pelaksanaan pembelajaran daring. Perlu dukungan orangtua/wali mahasiswa untuk menciptakan suasana belajar yang 
kondusif di lingkungan tempat tinggal sehingga pembelajaran daring tidak terganggu.

\section{DAFTAR PUSTAKA}

Arikunto, Suharsini, 2010. Prosedur Penelitian: Suatu Pendekatan Praktek. Bandung: Rineka Cipta

Ashari M, (2020). Proses Pembelajaran Daring di Tengah Antisipasi Penyebaran Virus Corona Dinilai Belum Maksimal, (online), (PikiranRakyatcom.

https://www.pikiranrakyat.com/pendidikan/pr01353818/proses-pembejalaran-daringdi-tengah-antisipasi-penyebaran-viruscorona-dinilai-belum-maksimal), diakses 12 September 2020

Buabeng-Andoh, Charles. 2012. International Journal of Education and Development using Information and Communication Technology (IJEDICT). Vol. 8, Issue 1, pp. 136-155

Dewi Wahyu, 2020. Dampak covid-19 terhadap implementasi pembelajaran daring di sekolah dasar. Edukatif Jurnal Ilmu pendidikan Universitas pahlawan tuanku tambusai.

DOI: https://doi.org/10.31004/edukatif. v2i1.89

John Hopkins University, 2020. COVID-19 Dashboard by the center of system science and engineering (CSSE), (online),

(https://www.arcgis.com/apps/opsdashb oard/index.html\#/bda7594740fd402994 23467b48e9ecf6), diakses 13 Oktober 2020 jam 08.00WIB

Kementerian pendidikan dan kebudayaan RI, 2020. Surat edaran Kementerian pendidikan dan kebudayaan No.15 tahun 2020 tentang pedoman penyelenggaraan belajar dari rumah dalam masa darurat penyebaran COVID-19

Komite penanganan covid-19 \& pemulihan ekonomi nasional, 2020. Pandemi covid-19, (online), (https://covid19.go.id/p/berita), diakes pada 1 September 2020 jam 08.00 WIB

Kurniawan, Nasir, 2014. Faktor-faktor yang mempengaruhi keberhasilan implementasi e-learning di kalangan mahasiswa perguruan tinggi swasta di kota Palembang. Prosiding seminar nasional penelitian dan PKM sains, teknologi dan kesehatan. Vol 4. No 01 Tahun 2014. Pp 501-512

Sumantri Arga. Metamorfosis Dunia Pendidikan di Masa Pandemi Covid-19 https://www.medcom.id/pendidikan/ins pirasi-pendidikan/JKRGWl5Nmetamorfosis-dunia-pendidikan-dimasa-pandemi-covid-19 diakses 8 September 2020

Widoyoko Eko P, 2010. Evaluasi program pembelajaran : panduan praktis bagi pendidik dan calon pendidik. Yogyakarta, pustaka belajar

Widyastuti A. Berita Tempo : Kecepatan internet RI nyaris terendah, (online),

(https://bisnis.tempo.co/read/1338150/k ecepatan-internet-ri-nyaris-terendahmenkominfo-sebut-6sebab/full\&view=ok), diakses pada 15 Agustus 2020

World Health Organization, 2020. Novel corona virus, (online), (https://www.who.int/indonesia/news/n ovel-coronavirus/qa-for-public), diakses diakes pada 1 September 2020 jam 08.00 WIB

Wulandari Nadiah, 2020. Dampak Pandemi Covid-19 Terhadap 
Pelaksanaan Pendidikan Di Indonesia, (online),

(https://pustakabergerak.id/artikel/damp

ak-pandemi-covid-19-terhadap-

pelaksanaan-pendidikan-di-indonesia-

2), diakses pada 10 September 2020 